\title{
DETERMINANTS OF NEET (NOT IN EMPLOYMENT, EDUCATION OR TRAINING) ON THE POLISH LABOUR MARKET
}

\author{
DETERMINANTY WYSTĘPOWANIA ZJAWISKA NEET (NOT IN EMPLOYMENT, \\ EDUCATION OR TRAINING) NA POLSKIM RYNKU PRACY
}

https://doi.org/10.34739/zn.2021.56.03

Anna M. Rak

Poland, Siedlce University of Natural Sciences and Humanities, Faculty of Social Sciences anna.rak@uph.edu.pl, ORCID: 0000-0002-5859-6252

JEL Classification Codes: J64

\begin{abstract}
The principal purpose of the study is to identify the individual risk factors of young people becoming the NEET generation on the Polish labour market. The first part of the paper comprises a literature-based overview of definitions of the NEET category based on a presentation of the risk factors of young people becoming NEET. The second part presents the results of empirical analyses conducted employing a questionnaire on a group of 120 individuals, aged 15 through 30, who met all criteria of the NEET definition set forth by the Employment Committee of the EU. The research demonstrates that among the major determinants of young people becoming NEET are the financial hardship of their households, low motivation to continue either formal education or change professional qualifications, and low levels of job-seeking activity.
\end{abstract}

Key words: NEET generation, labour market, young people

Streszczenie: Celem głównym artykułu jest identyfikacja indywidualnych czynników ryzyka przynależności osób młodych do generacji NEET na polskim rynku pracy. Na podstawie studiów literaturowych dokonano przeglądu definicji kategorii NEET oraz przedstawiono czynniki ryzyka przynależności osób młodych do tej kategorii. W części drugiej zaprezentowano wyniki badań empirycznych przeprowadzonych z wykorzystaniem kwestionariusza ankiety wśród 120 osób w wieku od 15 do 30 lat, spełniających wszystkie kryteria definicji NEET, określonej przez Komitet ds. Zatrudnienia UE. Badania wykazały, że do istotnych determinantów przynależności osób młodych do kategorii NEET należy trudna sytuacja dochodowa ich gospodarstw domowych, niski poziom motywacji do kontynuowania edukacji formalnej lub zmiany kwalifikacji zawodowych oraz niski poziom aktywności w zakresie poszukiwania zatrudnienia.

Słowa kluczowe: generacja NEET, osoby młode, rynek pracy

\section{Introduction - theoretical background}

NEET is a phenomenon which encapsulates the presence of a group of young people on a job market who are unemployed, professionally inactive, and non-participatory in any form of formal education or vocational training. As demonstrated by Eurostat's data, in the year 2020 in Poland, $17.4 \%$ of people aged $24-30$ were outside both the job market and the system of education. In the EU, in turn, the rate was on average $17.6 \%$, ranging from $8.2 \%$ in Holland to $29.4 \%$ in Italy. Given the foregoing, Poland's rate appears to be an average. This, however, does not change the fact that nearly 800 thousand young individuals do not work, study, or train.

The occurrence of NEET involves a number of undesirable economic, social, and individual costs. Money spent on education becomes an investment which generates losses, whereas an unused potential of intellectual capital can only lead to lost advantages. Thereby, the costs of investment of public funds and family funds in the education of the young generation do not. Moreover, social security benefits and maintenance of other institutions dealing with the support of the unemployed and the excluded generate high levels of expenditure. Therefore, the presence of the NEET generation in the society 
entails the cost of social insurance and professional reactivation of the young, combating crime and resocialisation. Staying outside the job market and being excluded from the system of education frequently are circumstances which often lead to poverty, marginalisation and social isolation, which coexist with various deviations and social dysfunctions (such as delinquency, alcoholism, drug addiction). What is more, no source of income and little chance of its acquisition are major barriers to the process of becoming autonomous, including young people's ability to start families and have children (Serafin-Juszczak, 2014, 54-55).

The objective of this study is to identify the individual risk factors of young people becoming NEET on the Polish labour market.

\section{Literature review}

The issue of young people not in education, employment or training was detected in the United States during the Great Recession. The term "idle youth" was coined to describe young people who did not take up jobs because there were none and who were not in education because of their poor intellectual ability. In the 1960s, the concerns of the rejected portion of the society and children dropping out of school became the research subject of Charles Murray, an American sociologist (Szcześniak, Rondón, 2011, 242).

The term NEET was first used in 1999 in the British government report Bridging the gap in the context of people aged 16 to 18 who were not in the labour force, education or training for at least 6 months (Rogozińska-Pawełczyk, 2014, 112). The report referred to the extent of the phenomenon in the United Kingdom, the reasons behind it, and possible solutions. The acronym NEET replaced the term "Status ZerO", which was used in previous British research in the field of young people activity on the labour market, quite quickly popularized and spread to other European Union states and elsewhere (Szcześniak, Rondón, 2011).

According to the definition provided by the UE Employment Committee (EMCO), based on the definition by the International Labour Organisation (ILO), the NEET category (Balcerowicz-Szkutnik, Wąsowicz, 2017, 9) includes:

- unemployed persons, not involved in any form of education or training,

- professionally passive persons, not involved in any form of education or training.

For the above definition to be more precise, we must determine the status of persons in education or training. Based on Eurostat, which considers the definition by ILO, a person is considered a participant in education or training whenever they are:
- in an apprenticeship, traineeship, or internship,

- in a government employment scheme or a training program,

- working or studying to obtain a qualification,

- participating in a system of education or professional training over a period of four weeks; preceding the statistical analysis,

- enrolled at an educational establishment and awaiting a course commencement or the retaking of a course.

The age category in the NEET's definition varies. In the majority of the European states, until recently the classification has comprised people aged between 15 and 24. Currently, however, mainly due to extended formal education, the upper age limit is represented by 29 . The 15 to 29 age bracket was adopted, amongst others, in the programming documents of the European Social Fund (Regulation (EU) no 1304/2013 of the European Parliament and of the Council of 17 December 2013). The same age brackets are applied by Eurostat for the purposes of NEET statistics. Nonetheless, to compare and portray changes occurring in the said group of young people, Eurostat has added the following extra age ranges: 15-19, 15-24, 20-24, 20-29, 25-29, 30-34 and 20-34. Outside Europe, for instance in Japan, NEET encompasses people aged 15 to 34 , who are either unemployed, not actively seeking employment, not in any type of education or training, or not involved in household chores (Furlong, 2007, 109).

In Poland, the upper age limit of the NEET generation was determined by the revised Act on the promotion of employment and labour market institutions and some other acts of 14 March 2014, which directed some special instruments of the labour market at people younger than 30 years of age. What is more, the upper age limit of the audience of the scheme entitled Guarantees for the youth in Poland was shifted from 25 to 29 . The decision was a consequence of Poland's commitment to extend high quality support to more young people entering the labour market and to harmonise target groups and the scope of EFS fund support, as well as of the Initiative for the employment of young people (as part of the priority axis of the I Operational Program Knowledge Education Development - PO WER). The PO WER program defines NEET as a person aged 15 to 29 who meets all three of the following conditions: does not work (i.e. is either unemployed or professionally passive), does not study (i.e. is not in formal education on a full-time basis - education in the school system at the level of primary school, lower secondary school, upper secondary school, at the level of higher education in the form of university degree or post-degree 
programs on a full-time basis), does not train (i.e. is not involved in any extra-curricular activities aimed at professional and general, work-related, skill and competence acquisition, supplementation or development).

The Exploring the diversity of NEETs (2016) Report by Eurofound specifies seven categories of people outside the system of education and the job market:

1) Re-entrants: This category captures those young people who will soon re-enter employment, education or training and will soon begin or resume accumulation of human capital through formal channels. They are people who have already been hired or enrolled in education or training.

2) Short-term unemployed: This category is composed of all young people who are unemployed, seeking work and available to start within two weeks, and have been unemployed for less than a year. A short period of unemployment during the transition from school to work can be considered normal, and the level of vulnerability among people in this category can be expected to be moderate.

3) Long-term unemployed: This category is composed of all young people who are unemployed, seeking work and available to start within two weeks, and have been unemployed for more than a year. People in this category are at high risk of disengagement and social exclusion. Longterm disengagement damages young people's employability, their human capital and their future employment outcomes; in some cases, the damage will last the rest of their lives.

4) Unavailable due to illness or disability: This category includes all young people who are not seeking employment or are not available to start a job within two weeks due to illness or disability. This group includes those who need more social support because illness or disability means they cannot do paid work.

5) Unavailable due to family responsibilities: This group includes those who are not seeking work or are not available to start a new job because they are caring for children or incapacitated adults, or have other less specific family responsibilities. Young people in this group are a mix of the vulnerable and non-vulnerable; some are not able to participate in the labour market because they cannot afford to pay for care for their child or adult family member, while others voluntarily withdraw from the labour market or education to take up family responsibilities.

6) Discouraged workers: This group captures all young people who have stopped looking for work because they believe that there are no job opportunities for them. They are mostly vulnerable young people at high risk of social exclusion who are very likely to experience poor employment outcomes over the course of their working lives.

7) Other inactive: This group contains all NEETs whose reasons for being NEET do not fall into any of the previous six categories. This group is a heterogeneous mix that includes the most vulnerable, those at risk of being deeply alienated, the most privileged, and those who are following alternative paths, careers.

The above-presented classification indirectly demonstrates the variability of the factors which precondition their belonging to the NEET generation. The NEET group captures both those who do not work of their own free will and those who do not work because, despite efforts, they fail to find employment. The category also includes those who are out of the educational and professional activity zone due to disability, illness, or caring for dependent household members. Moreover, NEET encompasses young graduates who completed education, are not able to find work, and at the same time are unwilling to participate in unpaid internships or work placements. Some of the NEETs have little influence over their situation, whereas others are not looking for a job or are unwilling to gain education, despite the fact that they have no responsibilities or health conditions. The factors accounted for in the NEET categorisation may overlap and result in an increased impact on the personal and professional standing of young people (Kurzawa, 2018). Without a doubt, none of the circumstances listed above jeopardises chances for gaining appropriate education or finding permanent employment or may be used as an excuse for one's passivity or discouragement (Rogozińska-Pawełczyk, 2014, 113). This is because young people have diverse educational and social resources which affect their abilities to meet the requirements related to the integration of global economic markets and the dynamically transforming technology (Olofsson, Panican, 2018).

Attention should be drawn to the fact that those who belong to one of the NEET categories are representatives of the youngest generating currently entering the work market, i.e. generation Z. Generation Z includes young people born post 1990 unaware of the reality without computers, smartphones, electronic gadgets or the Internet. On the one hand, (which is a substantial asset) they are at ease with modern technology and can simultaneously function in both the real and the virtual world. On the other hand, Internet-based life impairs their verbal communication abilities and 
makes development of interpersonal relationships more difficult. Furthermore, they have issues with concentration, attention-span and their assessment of information is superficial (Gzowska, Gęgotek, 2017, 110). Notwithstanding the above, they boast a good command of foreign languages, multitasking, diversity of interests, focus on selffulfilment and their own goals. Against a backdrop of their attitude to work, it is emphasised that they tend to be demanding and wish to quickly and without much effort climb the professional ladder (Kukla, Nowacka, 2019).

From the sociological and economical point of view, the NEET generations is heterogeneous and their common element is existence "at the cost of other people". The group is composed of both some relatively well-educated young people who cannot find work corresponding to their qualifications and poorly qualified people who prematurely terminated their school education. What the two groups have in common is a lack of motivation to continue formal education or change qualifications or a lack of interest in professional activity. Amongst the NEET members, there are also young people who use alternative, socially unaccepted, illicit forms of income generation.
The risk factors increasing the likelihood of belonging to the NEET categories may be of individual, social or economic nature (Krause, 2016; Saczyńska-Sokół, Łojko, 2016). In research practice, due to the complexity of a straightforward subscription of individual factors to only one of the listed categories, they are typically presented jointly. The studies conducted by Eurofound demonstrate that the factors featuring the highest risk levels are low level of education, sex, bad health condition and disability, belonging to immigration communities and originating from disadvantaged families, broken homes or from families affected by unemployment.

From yet another perspective, NEET risk factors are also defined as those present not only at micro (which is a reflection of personal characteristics of a young man) but also at mezo and macro levels (Szcześniak, Rondón, 2011). The mezo level indicates factors related to the imperfectness of educational institutions, which emphasises their role in the production of professional passivity. The macro level, on the other hand, captures socio-economic factors, amongst them the tendency to late transition to independent living (Table 1).

Table 1. Risk factors of young people belonging to the NEET generation

\begin{tabular}{|c|c|}
\hline \multicolumn{2}{|r|}{ Micro Level } \\
\hline Self-assessment: & $\begin{array}{ll}- & \text { low self-esteem, } \\
- & \text { failure to see one's skills and good points, } \\
- & \text { lack of strong feelings for effectiveness of one's actions, } \\
- & \text { limited self-trust, }\end{array}$ \\
\hline Social contacts: & $\begin{array}{l}- \text { asocial approach to the environment, } \\
-\quad \text { low level of interpersonal skills, } \\
-\quad \text { feeling discriminated, }\end{array}$ \\
\hline Resourcefulness: & $\begin{array}{l}-\quad \text { being pessimistic about the reality, } \\
\text { - } \quad \text { inability to manage difficult or risky life situations, }\end{array}$ \\
\hline $\begin{array}{l}\text { Inclination to take up action when } \\
\text { in education or looking for a job: }\end{array}$ & $\begin{array}{ll}- & \text { no motivation, } \\
\text { - } & \text { unwillingness to make efforts, work, or sacrifice, } \\
\text { - } & \text { inability to adapt to a new school or/and working environment, } \\
\end{array}$ \\
\hline Family factors: & $\begin{array}{l}\text { - low educational and cultural sensibility of the parents, } \\
\text { - compensating parental feelings with economic goods, which leads to } \\
\text { young people not taking responsibility for themselves of others, }\end{array}$ \\
\hline $\begin{array}{l}\text { The phenomenon of } \\
\text { "emerging adulthood": }\end{array}$ & $\begin{array}{l}\text { - increased intensity of disorientation and uncertainty, } \\
\text { - } \quad \text { adjourning of the moment of entering the adult life, } \\
\text { - } \text { the state of suspension and identity crisis related to the transition from the } \\
\text { stage of education to active participation in the job market, }\end{array}$ \\
\hline \multicolumn{2}{|r|}{ Mezo Level } \\
\hline Educational institutions/schools & $\begin{array}{l}\text { - absence of individualisation of the education process, } \\
\text { - limited scope of application of activation methods in the process of } \\
\text { knowledge, skills and social competence acquisition, } \\
\text { - } \text { taking decision about premature termination of education due to } \\
\text { discouragement by the institution of the school, } \\
\text { - inability of teachers to cope with pathological behaviours in and outside } \\
\text { the school environment, }\end{array}$ \\
\hline \multicolumn{2}{|r|}{ Macro Level } \\
\hline Social and economic processes: & $\begin{array}{l}- \text { economic crisis, } \\
-\quad \text { social loss of hope to find employment, } \\
-\quad \text { social connivance to remain in a family household for long periods. }\end{array}$ \\
\hline
\end{tabular}

Source: compiled on the basis of source literature (Szcześniak, Rondón, 2011; Rybicka, 2014). 
Research on young Poles from the NEET generation draw our attention also to institutional and cultural determinants. These comprise (Krause 2016, 74-75):

- long-term unemployment in the region - this pertains, above all, to remote regions away from the main communication paths, with limited access to public services,

- segmentation of the job market - i.e. the division of the local market into a stable segment of full-time employees and the market of seasonal workers employed under contracts featuring uncertainty,

- inflexibility of the job market - understood as unwillingness to employ graduates having no professional experience and simultaneous preference for hiring students,

- maladjustment of the quality of curricula to the needs of the job market resulting in incongruity of the competencies of young people and employees' expectations maladjustment of the system of education to the requirements of the job market.

\section{Methodology}

In Poland, the presence of the NEET phenomenon is accounted for mainly on the basis of mass statistics data, above all, the Central Statistical
Office (GUS), acquired as part of the Research on Economic Activity of the Polish Population (BAEL). Given the complexity of the issue and its adverse socio-economic effects, current knowledge must be broadened and it should become the starting point for the shaping of public policies which will truly limit the scope and consequences of the phenomenon.

The underlying objective of the research, the results of which are presented in this study, was to identify the individual risks of becoming the young NEET generation. The analysis was conducted with the application of a diagnostic survey with the use of the PAPI (Paper Assisted Personal Interviewing) technique. In the research process, a survey questionnaire was applied, with questions regarding, amongst other things, parent's education, income, reasons behind educational or training inactivity, and job-seeking activities. The studies, conducted in the 1st quarter of 2020, included 120 people, aged 15 through 30 , who met all of the criteria of the NEET definition set forth by the Employment Committee of the EU. The general characteristics of the respondents are shown in Table 2.

Table 2. Overview of Respondents

\begin{tabular}{lcc}
\multicolumn{1}{c}{ Specification } & $\begin{array}{c}\text { Number } \\
\text { of respondents }\end{array}$ & \% Respondents \\
\hline Sex: & 73 & 60.8 \\
Male & 47 & 39.2 \\
Female & & \\
\hline Age: & 48 & 40.0 \\
15-24 & 72 & 60.0 \\
25-30 & & \\
\hline Job market status: & 68 & 56.7 \\
$\quad$ unemployed registered with the poviat labour office & 52 & \\
professionally inactive & 27 & 22.5 \\
Education: & 29 & 24.2 \\
Higher/Tertiary & 45 & 37.5 \\
General Secondary & 19 & 15.8 \\
Vocational/Post-Secondary Non-Tertiary & & \\
Basic Vocational, Lower Secondary \& Primary & 40 & 33.3 \\
\hline Residence: & 30 & 25.0 \\
countryside & 50 & 41.7 \\
town, population size $<50.000$ & & \\
city/town, population size $>50.000$ & & \\
\hline
\end{tabular}

Source: compiled on the basis of own research.

The data shows that $60.8 \%$ of the study population was male. The majority of the population were people aged 25-30 (60.0\%) awarded a formal status of an unemployed person $(56.7 \%)$, residing in cities/towns with a population exceeding 50.000 (41.7\%). The level of education of the respondents was quite diversified, but the largest group (37.5\%) included post-secondary non-tertiary and vocational graduates. 


\section{Results and discussion}

As demonstrated by current research (NEETs Young people not in employment, education or training: Characteristics, costs and policy responses in Europe, 2012), one of the key risks of young people becoming NEET is low income of their households. This is evidenced by the author's own research presented in Table 3 . In every education-based group, financial situations of households are definitely tough. In the households of 118 respondents ( $98.3 \%$ of the total), the monthly net income per capita was lower than that of an average Polish household, which according to the 2020 GUS's data averaged around PLN 1919.

The most typical source of income for households was wage labour; it was most essential for higher, general secondary, secondary vocational and post-secondary non-tertiary education level households. In nearly $25.0 \%$ of the households with members of basic vocational and lower-level education, social benefits also played a major role. What is worrying, is that approximately $25.0 \%$ of respondents of higher and general secondary level education, as well as
$22.0 \%$ of respondents of vocational and postsecondary non-tertiary, and basic vocational and lower-level education, generate their income from black economy jobs. This suggests a low awareness of the consequences which this form of employment entails. First of all, employment not based on any kind of contract does not guarantee timely wages or wages at all. Secondly, a black economy job is not included in one's job experience or seniority, which is vital when determining one's right to pension. An employee who is not registered with the Social Insurance Institution (ZUS) is deprived of health insurance, which deprives one of an ability to avail of free public healthcare benefits. Additionally, undeclared work means no employee rights, e.g. holiday leaves. Black labour issues no guarantee that an employee would receive wages in the case of an illness and working hours may not be followed. Furthermore, there is no certainty that a job would be performed in safe and decent conditions. From the point of view of young people, black economy jobs of their household members are wrong models for them to follow in terms of job market behaviour.

Table 3. Income of households of the studied NEET generation members by education

\begin{tabular}{|c|c|c|c|c|c|c|c|c|}
\hline \multirow[t]{2}{*}{ Specification } & \multicolumn{2}{|c|}{ Higher/Tertiary } & \multicolumn{2}{|c|}{ General Secondary } & \multicolumn{2}{|c|}{$\begin{array}{c}\text { Vocational } \\
\text { Post-Secondary } \\
\text { Non-Tertiary }\end{array}$} & \multicolumn{2}{|c|}{$\begin{array}{c}\text { Basic vocational } \\
\text { and lower }\end{array}$} \\
\hline & number & $\%$ & number & $\%$ & number & $\%$ & number & $\%$ \\
\hline \multicolumn{9}{|c|}{ Average monthly net income per 1 person in a household } \\
\hline below PLN 500 & 3 & 11.1 & 8 & 27.6 & 13 & 28.9 & 5 & 26.3 \\
\hline PLN 500-1000 & 13 & 48.2 & 18 & 62.1 & 28 & 62.2 & 12 & 63.2 \\
\hline PLN 1001-1500 & 10 & 37.0 & 2 & 6.9 & 4 & 8.9 & 2 & 10.5 \\
\hline Over PLN 1500 & 1 & 3.7 & 1 & 3.4 & - & - & - & - \\
\hline \multicolumn{9}{|c|}{ Source of income of the respondent's household } \\
\hline & number & $\begin{array}{c}\% \text { of } \\
\text { indications }\end{array}$ & number & $\begin{array}{c}\% \text { of } \\
\text { indications }\end{array}$ & number & $\begin{array}{c}\% \text { of } \\
\text { indications }\end{array}$ & number & $\begin{array}{c}\% \text { of } \\
\text { indications }\end{array}$ \\
\hline wage labour & 32 & 55.2 & 26 & 41.2 & 36 & 50.0 & 9 & 27.3 \\
\hline pension & 3 & 5.2 & 7 & 11.3 & 5 & 6.7 & 4 & 12.1 \\
\hline $\begin{array}{l}500+\text { benefit, } \\
\text { social security } \\
\text { benefits }\end{array}$ & 5 & 8.6 & 9 & 14.5 & 12 & 16.0 & 8 & 24.2 \\
\hline black economy job & 15 & 25.9 & 16 & 25.8 & 17 & 22.7 & 7 & 21.2 \\
\hline other & 3 & 5.2 & 4 & 6.5 & 5 & 6.7 & 5 & 15.1 \\
\hline
\end{tabular}

Source: compiled on the basis of own research.

Data presented in Table 4 demonstrate that a large part of respondents $(42.5 \%)$ does not continue education or training because they find their current levels of qualification and professional competencies satisfactory. This is reflected by the results published in the report entitled Wsparcie młodych osób na mazowieckim rynku pracy (Support to young people on the Mazowiecki 
labour market) published by Mazowieckie Obserwatorium Rynku Pracy (Mazowieckie Observatory of Labour Market). What is surprising is that the said argument is oftentimes raised by people with a general secondary education level $(69.7 \%$ of the total of individuals in this same category). It is the only category whose position on the Polish job market has lately distinctly deteriorated due to the decreasing demand for unqualified workers.

Among the respondents with basic vocational and lower-level education, educational and training inactivity originated from their lack of conviction that taking up any further educational course or training would improve their job market situation $(40.1 \%$ of the total indications of people in the said category) and from financial difficulties (31.8\% of the total). Here, it should be emphasised that a lack of financial resources to enrol in a program of education is true, to a various extent, also in the case of the remaining educational groups. Given the previously discussed income situation of respondents' households, we may claim that a lack of financial resources to fund further levels of formal education or training is the real reason behind any discontinuance of qualification and professional competency development.

The respondents who most frequently highlighted poor educational and training market offers were possessed of a basic vocational and lower-level education. These are people seeking abilities to acquire specific entitlements and certificates providing a chance of employment as qualified blue-collar workers. As part of professional activation campaigns conducted by poviat employment offices, such offers indeed are a relatively rare occurrence.

Table 4. Reasons for the educational and training inactivity of the studied NEET generation members by education

\begin{tabular}{|c|c|c|c|c|c|c|c|c|}
\hline \multirow{2}{*}{ Specification } & \multicolumn{2}{|c|}{ Higher/Tertiary } & \multicolumn{2}{|c|}{$\begin{array}{c}\text { General } \\
\text { Secondary }\end{array}$} & \multicolumn{2}{|c|}{$\begin{array}{c}\text { Vocational } \\
\text { Post-Secondary } \\
\text { Non-Tertiary } \\
\end{array}$} & \multicolumn{2}{|c|}{$\begin{array}{l}\text { Basic vocational } \\
\text { and lower }\end{array}$} \\
\hline & number & $\begin{array}{c}\% \text { of } \\
\text { indications }\end{array}$ & number & $\begin{array}{c}\text { \% of } \\
\text { indications }\end{array}$ & number & $\begin{array}{c}\% \text { of } \\
\text { indications }\end{array}$ & number & $\begin{array}{c}\% \text { of } \\
\text { indications }\end{array}$ \\
\hline $\begin{array}{l}\text { Satisfactory level of } \\
\text { education }\end{array}$ & 13 & 44.8 & 23 & 69.7 & 14 & 24.6 & 1 & 4.5 \\
\hline $\begin{array}{l}\text { Lack of conviction that } \\
\text { further education/training } \\
\text { would improve respondent': } \\
\text { situation on the job market }\end{array}$ & 2 & 6.9 & - & - & 7 & 12.3 & 9 & 40.1 \\
\hline Financial difficulties & 5 & 17.2 & 5 & 15.2 & 15 & 26.3 & 7 & 31.8 \\
\hline $\begin{array}{l}\text { Lack of knowledge about } \\
\text { educational and training } \\
\text { offers }\end{array}$ & 3 & 10.3 & 1 & 3.0 & 5 & 8.8 & - & - \\
\hline $\begin{array}{l}\text { Lack of suitable } \\
\text { educational and training } \\
\text { offers }\end{array}$ & 2 & 6.9 & - & - & 3 & 5.3 & 3 & 13.6 \\
\hline $\begin{array}{l}\text { Duties related to } \\
\text { childcare }\end{array}$ & - & - & 1 & 3.0 & 8 & 14.0 & - & - \\
\hline Other & 4 & 13.8 & 3 & 9.1 & 5 & 8.8 & 2 & 9.1 \\
\hline
\end{tabular}

Source: compiled on the basis of own research.

Those who undertook job-seeking activities used, on average, two methods (Table 5). The most popular one was an analysis of employment office's job offers. This form of job-seeking was pursued by nearly one-third of people of general secondary education, post-secondary non-tertiary, secondary vocational education, and basic vocational or lower education levels, and onefourth of the holders of a tertiary-level diploma. However, we ought to emphasise that $56.7 \%$ of the total of respondents are registered with poviat employment offices, for whom the analysis of job offers is the condition necessary to maintain the status of an unemployed person. This demonstrates that such job-seeking activities have been formally imposed upon them.

A common job-seeking practice observed in every educational group was also to follow job openings published in the media. The respondents searching for jobs in the media indicated they did 
so mostly via internet sites. Other popular activities of the interviewees were the contacts of friends and family $(23.4 \%$ of indications in the group of basic vocational level education and lower, $20.0 \%$ in the groups of higher and general secondary education, and $17.6 \%$ in the group of vocational and post-secondary non-tertiary education). The methods most typically indicated by respondents are, at the same time, those most popular among the unemployed in Poland in accordance with the results of BAEL (Economic activity of the Polish population - 4th quarter 2020, 2021).
The research findings show that respondents relatively rarely avail of job-seeking methods which would require engagement and suitable preparation. Such activities would include, among others, visiting places of employment in person or sending offers to employers. Therefore, one may conclude that respondents' activity with respect to job-seeking is often solely declarative. Finally, it should be emphasised that there is no clear link between the job-seeking method used and the level of education of the studied population.

Table 5. Respondents' job-seeking activities

\begin{tabular}{|c|c|c|c|c|c|c|c|c|}
\hline \multirow[t]{2}{*}{ Specification } & \multicolumn{2}{|c|}{ Higher/Tertiary } & \multicolumn{2}{|c|}{$\begin{array}{c}\text { General } \\
\text { Secondary }\end{array}$} & \multicolumn{2}{|c|}{$\begin{array}{c}\text { Vocational } \\
\text { Post-Secondary } \\
\text { Non-Tertiary }\end{array}$} & \multicolumn{2}{|c|}{$\begin{array}{l}\text { Basic vocational } \\
\text { and lower }\end{array}$} \\
\hline & $\begin{array}{l}\text { number of } \\
\text { indications }\end{array}$ & $\%$ & $\begin{array}{l}\text { number of } \\
\text { indications }\end{array}$ & $\%$ & $\begin{array}{l}\text { number of } \\
\text { indications }\end{array}$ & $\%$ & $\begin{array}{r}\text { number of } \\
\text { indications }\end{array}$ & $\%$ \\
\hline $\begin{array}{l}\text { Analysis of the offer } \\
\text { of employment offices }\end{array}$ & 20 & 26.6 & 24 & 28.6 & 37 & 27.2 & 13 & 27.7 \\
\hline $\begin{array}{l}\text { Placing one's own } \\
\text { announcement in the } \\
\text { media }\end{array}$ & 2 & 2.7 & - & - & 9 & 6.6 & 3 & 6.4 \\
\hline $\begin{array}{l}\text { Analysing } \\
\text { media announcements }\end{array}$ & 18 & 24.0 & 22 & 26.2 & 35 & 25.7 & 12 & 25.5 \\
\hline $\begin{array}{l}\text { Efforts made to take up } \\
\text { a job abroad }\end{array}$ & 1 & 1.3 & 2 & 2.4 & 3 & 2.2 & - & - \\
\hline $\begin{array}{l}\text { Use of family's and } \\
\text { friends' help }\end{array}$ & 15 & 20.0 & 17 & 20.2 & 24 & 17.6 & 11 & 23.4 \\
\hline $\begin{array}{l}\text { Sending offers to } \\
\text { employers }\end{array}$ & 5 & 6.7 & - & - & 4 & 2.9 & 2 & 4.3 \\
\hline $\begin{array}{l}\text { Visiting places of } \\
\text { employment in person }\end{array}$ & 12 & 16.0 & 17 & 20.2 & 22 & 16.2 & 4 & 8.5 \\
\hline Job-seeking inactivity & 2 & 2.7 & 2 & 2.4 & 2 & 1.5 & 2 & 4.3 \\
\hline
\end{tabular}

Source: compiled on the basis of own research.

\section{Conclusions}

In the studied NEET population, there were both people unemployed and professionally inactive who, over the four weeks preceding the study, had not participated in any form of education or training.

The results of the conducted research show that these are individuals in a difficult financial situation which clearly limits their ability to pursue education or undertake training. Nonetheless, educational or training inactivity was most often justified by the fact that their levels of education were already satisfying. What is surprising, is that such argumentation was presented by a very numerous group of general secondary-school graduates, whose competencies and professional qualifications are the lowest of all the specified educational groups.
The vast majority of the studied population declared a wish to change their situation on the job market by, above all, taking up employment. Nearly all of the studied youth demonstrated activities aimed at finding a job. The dominant jobseeking methods included following job openings published by poviat employment offices, browsing through offers posted online, and availing of the help of family and friends. These are the methods which do not require greater involvement on the part of job seekers, which proves job seeking to be rather declarative in nature, job-seeking inability and social exclusion.

The picture of the representatives of the NEET category that emerges from the research study is that of people in difficult circumstances, of low motivation to pursue formal education or change professional qualifications, who demonstrate poor job-seeking skills. They are individuals whose life situation may change only upon an introduction of 
complex institutional solutions that would guarantee real support to their development and professional activity.

\section{References}

Aktywność ekonomiczna ludności Polski - IV kwartał 2020 [Labour force survey in Poland quarter 4/2020]. (2021). Warszawa: Główny Urząd Statystyczny.

Balcerowicz-Szkutnik, M., Wąsowicz, J. (2017). Pokolenie NEETs na rynku pracy - aktualne problemy [NEETs generation on the labour market - current problems]. Studia Ekonomiczne. Zeszyty Naukowe Uniwersytetu Ekonomicznego w Katowicach 312 (9), 7-17.

Furlong, A. (2007). The zone of precarity and discourses of vulnerability: NEET in the UK. Journal of Social Sciences and Humanities (381), 101-121.

Gzowska, W., Gęgotek, S. (2017). Zarządzanie współpracą międzygeneracyjną pracowników. Uwarunkowania współczesnego rynku pracy oraz zróżnicowanie pokoleń [Management the intergenerational cooperation between employees. Conditions influence the present-day labour market and diversification of generations]. Humanum Międzynarodowe Studia SpołecznoHumanistyczne 26 (3), 97-111.

Kause, E. (2016). Zjawisko NEET, czyli o młodzieży trzy razy nic [The NEET Phenomenon, or about the three Times nothing youth] Zeszyty Naukowe Uniwersytetu Zielonogórskiego i Polskiego Towarzystwa Profesjologicznego 2, 67-81.

Kukla D., Nowacka M. (2019). Charakterystyka podejścia do pracy przedstawicieli pokolenia Z - praca w systemie wartości młodych. Cz. 1 [Characteristics of the approach to work by the representatives of Generation Z - work in the system of young values. Part 1]. Edukacja Ustawiczna Dorostych 3, 120-130.

Kurzawa, I. (2018). Generacja NEET w Polsce i wybranych krajach Unii Europejskiej [NEET generation in Poland and selected countries of the European Union]. Prace Naukowe Uniwersytetu Ekonomicznego we Wrocławiu 529, 150-161.

Mascherini, M., Ledermaier, S. (2016). Exploring the diversity of NEETs. Eurofound. https://www.eurofound.europa.eu/sites/default/ files/ef_publication/field_ef_document/ef1602e n.pdf. DOI: $10.2806 / 62307$.

NEETs Young people not in employment, education or training: Characteristics, costs and policy responses in Europe (2012). Luxembourg: Publications Office of the European Union.
Olofsson, J., Panican, A. (2018). Apprenticeship training in upper secondary school, movies and possibilities from a Swedish and European perspective. In: M.A. Malo, A. Moreno (Eds.), European Youth Labour Markets: Problems and Polices (pp. 79-92). Switzerland: Springer International Publishing AG.

Regulation (EU) No 1304/2013 of the European Parliament and of the Council of 17 December 2013 on the European Social Fund and repealing Council Regulation (EC) no 1081/2006.

Rogozińska-Pawełczyk, A. (2014). Pokolenie NEET czyli młodzież bez pracy, nauki i szkolenia: charakterystyka, koszty i rozwiązania polityczne na przykładzie Europy. In: A. Rogozińska-Pawełczyk (Eds.), Pokolenia na rynku pracy [Generations on the labour market] (pp. 111-126). Łódź: Wydawnictwo Uniwersytetu Łódzkiego.

Rybicka, K. (2014). Sytuacja młodzieży na polskim rynku pracy [The situation of young people on the Polish labor market]. Studia i Prace Wydziału Nauk Ekonomicznych i Zarządzania Uniwersytetu Szczecińskiego 37 (2), 105-116.

Saczyńska-Sokół, S., Łojko, M. (2016). Sytuacja młodzieży NEET na rynku pracy [The situation of NEETs on the labor market]. Zeszyty Naukowe UPH w Siedlcach $\mathrm{nr}$ 108. Seria: Administracja i Zarządzanie (35), 97-107.

Serafin-Juszczak, B. (2014). NEET - nowa kategoria młodzieży zagrożonej wykluczeniem społecznym [NEET - young people vulnerable to social exclusion]. Acta Universitatis Lodziensis. Folia Sociologica 49, 45-61.

Szcześniak, M., Rondón, G. (2011). Pokolenie „ani-ani”: o młodzieży, która się nie uczy, nie pracuje i nie dba o samokształcenie ["Neithernor" generation: About young people who are not in education, employment, or training]. Psychologia Społeczna 3 (18), 241-251.

Ustawa z dnia 14 marca 2014 r. o promocji zatrudnienia $\mathrm{i}$ instytucjach rynku pracy oraz niektórych innych ustaw. Dz.U. z 2014 r., nr, poz. 598 z późn. zm. [Act of March 14, 2014. Employment promotion and labor market institutions]. 